\title{
THE COMPARISON OF SENSORY QUALITY AND PROCESSING POTENTIAL OF 'TOPAZ' APPLES GROWN IN ORGANIC ORCHARDS AND ORCHARDS MANAGED IN INTEGRATED PRODUCTION SYSTEM
}

\author{
Dorota Konopacka ${ }^{1}$, Urszula Kaczmarek ${ }^{1}$, Aneta Matulska ${ }^{1}$, \\ Anna Wawrzyńczak ${ }^{1}$, Dorota Kruczyńska ${ }^{2}$ \\ and Krzysztof P. Rutkowski ${ }^{1}$ \\ ${ }^{1}$ Department of Fruit Storage and Processing \\ ${ }^{2}$ Department of Pomology, Genetic Resources and Nursery \\ Research Institute of Horticulture \\ 96-100 Skierniewice, Konstytucji 3 Maja 1/3, POLAND \\ e-mail: dorota.konopacka@inhort.pl
}

(Received Novembr 22, 2012/Accepted December 14, 2012)

\section{A B S T R A C T}

The aim of the study was to compare the sensory quality of scab resistant 'Topaz' apples grown in certified organic orchards (ECO) with those grown in orchards managed within integrated method (IP), and to determine their potential processing suitability. Fruits were harvested in five certificated IP and ECO orchards at the optimum ripeness stage and stored for two months in normal atmosphere at $1{ }^{\circ} \mathrm{C}$. Apple quality was assessed one day after cold storage and after 7 days of storage at the temperature $18^{\circ} \mathrm{C}$ to simulate shelf life. The results of taste and flavour sensory assessment did not explicitly demonstrate the effect of the orchard management system on the overall eating quality. Although the fruits from the organic orchards were perceived as less sweet and sourer, the management system did not influence the overall eating quality. There was no effect of the growing technology on quality traits connected with aroma and overall texture assessment. Regarding appearance evaluation, fruits from organic orchards were characterized by a higher variation in shape and size, and more frequently than in the case of IP apples had blemishes, scars and rust, which negatively affected their attractiveness. Analysis of the chemical composition of fruits indicates that apples from organic orchards are characterized on average by higher titratable acidity and higher soluble solids content than apples from IP orchards, which could favour their potential application as the additive regulating acidity and shaping the desirable sensory traits of processed organic products.

Key words: organic production, fruit quality, sensory attractiveness, chemical composition, processing usefulness 
D. Konopacka et al.

INTRODUCTION

The increasing interest of consumers in food safety and healthiness favours the development of organic fruit growing. In Poland, the organic food production and consumption is still not very popular, but the amount of organic food consumers is growing. Although a dynamic increase of organic farms, accompanied by an increasing number of organic processing plants, may be observed (Zmarlicki, 2009), their amounts are still lower than in other countries in which development of organic production is much more advanced, as in Switzerland, Austria or Denmark. One of the most serious barriers for organic production in Poland is the elevated price of organic food that in the case of fruits (i.e. apples or strawberries) is twice higher than for regular (or managed in integrated production system) products. Furthermore, limited access to information on the rules of organic farming, as well as poor accessibility of the organic food products, had been indicated as barriers for further development of organic food consumption (Zmarlicki, 2009; Weibel et al., 2012). Besides, there is worse appearance of organic fruits than those grown conventionally, resulting from pest or pathogen damage that affect their visual attractiveness (Adamczyk et al., 2006; Cmelik et al., 2007). The technology of organic fruit production excludes any means of crop protection using chemically-synthesized products. The only ones allowed are natural substances (WE, 2007). These limitations cause that pests and diseases protection became the most difficult element of organic apple production (Bryk, 2006). One of the possibilities to handle these restrictions, and to produce organic apple fruit of high quality, is to use cultivars resistant to apple scab (Venturia inaequalis). Amongst available scab resistant apple cultivars 'Topaz' is one the most often recommended for organic orchards (Czynczyk et al., 2008; Kruczyńska and Rutkowski, 2006; Pitera, 2006). Despite of occasional reports that some scab races overcome the resistance of 'Topaz' (Vavra and Bocek, 2010, Bryk and Kruczynska, 2011), this cultivar is considered as highly promising for orchards managed within organic system. 'Topaz' fruit has more advantages - this cultivar loses its firmness and its characteristic sour taste slower than fruit of other scab-resistant cultivars, even during long storage (Konopacka et al., 2006). Therefore, it has high trade potential being highly attractive not only as fresh fruit for direct consumption but also as raw material for home-made preserves or commercial processing.

The aim of the study was to compare the sensory quality and processing potential of scab resistant 'Topaz' apples produced in certified organic orchards (ECO) with those produced in orchards using integrated methods (IP).

\section{MATERIAL AND METHODS}

The experiment was conducted in 2010 season at the Research Institute 
The comparison of sensory quality and processing...

of Horticulture in Skierniewice (IO). Apple fruits of 'Topaz' cultivar were collected in five certified organic orchards (ECO) and in five certified orchards in which integrated technology (IP) was used. All orchards were located in the central region of Poland. The ECO and IP orchards were matched in pairs (A-E) according to geographical proximity and/or climate-soil similarity. In all cases, fruits were collected from the trees grafted on M.26 rootstock, grown in the mid-intensity (12501500 trees/ha). Fruits were picked at the harvest maturity recommended for fruit destined for storage (internal procedures of IO Fruit Storage Department). Nevertheless in some commercial IP orchards (B, D and E), the harvesting date was intentionally delayed due to weak (unsatisfied) blush colour. The postponing time was controlled by regular checking of ethylene concentration in the seed cavity, not to exceed the values characteristic for pre-climacteric stage. Immediately after harvest fruits were transported to storage facilities of IO. Fruit taken for storage were matched in size, shape and colour and had no visible marks of mechanical or microbial damage. Before storage, each batch of apples was subjected to routine analyses that allow characterization of fruit maturity. Among others ethylene concentration in seed cavities, starch index, skin blush percentage, firmness, soluble solids and titratable acidity were determined. Fruits were stored for two months at $1{ }^{\circ} \mathrm{C}$. The quality of stored apples was assessed one day after cold storage and after 7 days of storage at the temperature $18{ }^{\circ} \mathrm{C}$ to simulate shelf life. The quality characteristics analyses covered soluble solids and titratable acidity (taken as a measure of processing usefulness and indicators of sugar/acid balance), physical characteristic of apple texture (firmness and juiciness) and the sensory assessment including external as well as internal (eating) quality attributes. For each orchard, and the checking date 15 apples were tested (altogether - 150 apples for each technology: 5 orchards $x$ 1 picking date $\mathrm{x} 2$ checking dates $\mathrm{x}$ 15 apples $=150$ apples). From each sample 10 fruits were subjected to instrumental measurements and then sensory assessment while 5 fruits were presented as sample for appearance evaluation. The instrumental analyses consisted of the following measurements: firmness (N) by penetrometer method with the Magness-Taylor probe of $11.1 \mathrm{~mm}$ diameter (Instron texture press 4303), juiciness index (\%) according to Konopacka and Płocharski (2001); acidity with potentiometric method by titration to $\mathrm{pH} 8.1$ and calculation to malic acid content (\%), and soluble solids contents of freshly squeezed fruit juice by refractometric method (\%). For sensory assessment of stored apples, the scaling-profiling method was used. The data were collected through the computerized data collecting system "ANALSENT NT" (Caret, Systemy Cyfrowe, Polska) developed at the Polish Academy of Sciences, Warsaw, Poland. 27 qualitative traits connected with 


\section{Konopacka et al.}

appearance, aroma, taste and texture of tested fruits that can influence potential buyers' perception were evaluated. In the current paper only the attributes that significantly impact the quality of compared apple batches are to be discussed while others such as astringency, or odd-taste that were not noticed in this experiment, were omitted. Each attribute was rated on a continuous linear scale with anchor points at each end, marked as 0 and 100 points. In the case of sensory assessment 0 denotes lack/low intensity or inappropriate harmonization of evaluated characteristic, and 100, high intensity or very good harmonization of the evaluated attribute. The gathered data were then transposed to numeric values considering the whole scale to be 10 subjective units. In the case of external quality assessment, the description of the scale is given together with results (see Table 4). The expert panel consisted of 10 judges recruited from the staff of the Research Institute of Horticulture, trained and having longstanding experience in sensory assessment of horticulture products. The apple sample for internal (eating) quality evaluation was served as peeled quarter placed in individual plastic container covered with a lid.

The data were elaborated statistically using STATISTICA 8.0 software package (Stat Soft Inc., Tulsa, USA). The differences between means were determined by the one and two-ways analysis of variance (ANOVA) and Duncan's multiple range test at $\mathrm{p}=0.05$.

\section{RESULTS AND DISCUSSION}

\section{Objective quality characteristics}

In Table 1 quality characteristics of fruit after picking are given. Considering blush percentage it may be noticed that fruit grown in organic orchards (ECO) reached its harvesting maturity earlier than those produced by integrated method (IP). However, at the same time fruit produced in organic orchard (ECO) were characterised by higher firmness and also by significantly higher titratable acidity. Similar results were previously reported by several researchers (Wiebel et al., 2000; Błaszczyk, 2006; Cmelik et al., 2007; Dangour et al., 2009). In the case of orchards, where the harvesting date of IP fruit was intentionally delayed to increase their blush intensity (B, D and E), the differences in titratable acidity between ECO and IP fruit became more distinct. Results obtained after two months of storage at normal atmosphere conditions (at $1{ }^{\circ} \mathrm{C}$ ) as well as after additional 7 days of ripening at $18^{\circ} \mathrm{C}$ (shelf life period) confirmed the differences between fruits produced in organic orchards and those produced by integrated methods (Tab. 2). The quality indices measured show consistently higher firmness and titratable acidity for fruit produced in organic orchards, as well as indicate their higher juiciness and soluble solids contents compared to IP fruit. 
The comparison of sensory quality and processing...

Table 1. Apple quality at the harvest time

\begin{tabular}{|c|c|c|c|c|c|c|}
\hline 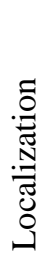 & 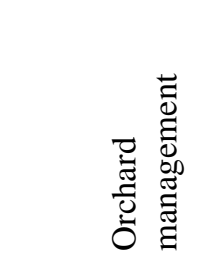 & 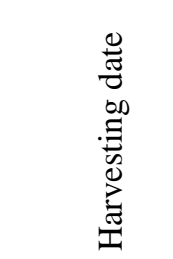 & 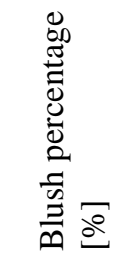 & 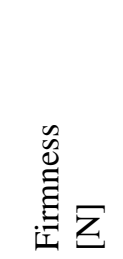 & 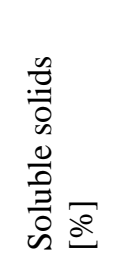 & 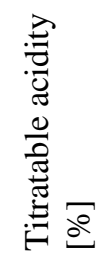 \\
\hline \multirow{2}{*}{ A } & ECO; organic & 04.10 .2010 & 72 bcd * & $88.0 \mathrm{f}$ & $12.9 \mathrm{~cd}$ & $1.09 \mathrm{f}$ \\
\hline & IP; integrated & 05.10 .2010 & $58 \mathrm{a}$ & $81.7 \mathrm{e}$ & $12.8 \mathrm{bc}$ & $1.04 \mathrm{e}$ \\
\hline \multirow{2}{*}{ B } & ECO; organic & 07.10 .2010 & - & $102.6 \mathrm{~g}$ & $13.3 \mathrm{e}$ & $1.14 \mathrm{~g}$ \\
\hline & IP; integrated & 21.10 .2010 & $68 \mathrm{~b}$ & $73.5 \mathrm{a}$ & $12.6 \mathrm{~b}$ & $0.95 \mathrm{~d}$ \\
\hline \multirow{2}{*}{$\mathrm{C}$} & ECO; organic & 12.10 .2010 & $89 \mathrm{f}$ & $82.7 \mathrm{e}$ & $13.9 \mathrm{~g}$ & $1.09 \mathrm{f}$ \\
\hline & IP; integrated & 12.10 .2010 & $53 \mathrm{a}$ & $74.4 \mathrm{ab}$ & $12.1 \mathrm{a}$ & $0.85 \mathrm{c}$ \\
\hline \multirow{2}{*}{ D } & ECO; organic & 08.10 .2010 & $70 \mathrm{bc}$ & $80.3 \mathrm{ed}$ & $13.7 \mathrm{f}$ & $1.23 \mathrm{~h}$ \\
\hline & IP; integrated & 25.10.2010 & 75 cde & $76.7 \mathrm{bg}$ & $14.4 \mathrm{~h}$ & $0.77 \mathrm{~b}$ \\
\hline \multirow[b]{2}{*}{ E } & ECO; organic & 07.10 .2010 & $78 \mathrm{e}$ & $78.3 \mathrm{~cd}$ & $13.0 \mathrm{~d}$ & $1.05 \mathrm{e}$ \\
\hline & IP; integrated & 29.10 .2010 & $77 \mathrm{de}$ & $74.9 \mathrm{ab}$ & $14.0 \mathrm{~g}$ & $0.74 \mathrm{a}$ \\
\hline
\end{tabular}

*Means in columns marked with the same letter do not significantly differ, Duncan MPR test, $\mathrm{p}<0.05$

Table 2. The influence of orchard management and shelf life on quality parameters of `Topaz` apple

\begin{tabular}{|c|c|c|c|c|c|c|c|c|}
\hline \multirow{3}{*}{$\begin{array}{c}\text { Shelf life } \\
\text { (days) }\end{array}$} & \multicolumn{2}{|c|}{$\begin{array}{l}\text { Firmness } \\
{[\mathrm{N}]}\end{array}$} & \multicolumn{2}{|c|}{$\begin{array}{c}\text { Juiciness } \\
{[\%]}\end{array}$} & \multicolumn{2}{|c|}{$\begin{array}{c}\text { Soluble solids } \\
{[\%]}\end{array}$} & \multicolumn{2}{|c|}{$\begin{array}{c}\text { Titratable } \\
\text { acidity } \\
{[\%]}\end{array}$} \\
\hline & \multicolumn{8}{|c|}{ orchard management } \\
\hline & 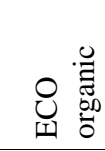 & 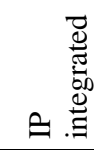 & 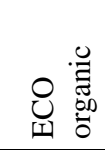 & 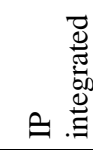 & ○ & 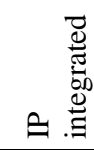 & 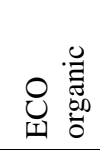 & 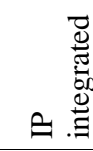 \\
\hline 1 & $74.1 \mathrm{a}^{*}$ & $69.8 \mathrm{~b}$ & $35.1 \mathrm{a}$ & $32.1 \mathrm{~b}$ & $14.8 \mathrm{a}$ & $13.9 \mathrm{~b}$ & $0.87 \mathrm{a}$ & $0.69 \mathrm{c}$ \\
\hline 7 & $67.2 \mathrm{~b}$ & $61.3 \mathrm{c}$ & $32.0 \mathrm{~b}$ & $31.0 \mathrm{~b}$ & $14.5 \mathrm{a}$ & $13.9 \mathrm{~b}$ & $0.77 \mathrm{~b}$ & $0.64 \mathrm{c}$ \\
\hline Average & $70.8 \mathrm{~A}$ & $65.6 \mathrm{~B}$ & $33.6 \mathrm{~A}$ & $31.5 \mathrm{~B}$ & $14.7 \mathrm{~A}$ & $13.9 \mathrm{~B}$ & $0.82 \mathrm{~A}$ & $0.67 \mathrm{~B}$ \\
\hline
\end{tabular}

*means marked with the same letter do not significantly differ, Duncan MPR test, $\mathrm{p}<0.05$ 
D. Konopacka et al.

\section{Eating quality assessment}

The obtained results of instrumental measurement generally stayed in consensus data gathered by sensory panel (Tab. 3). The assessors confirmed higher firmness of the organic apples both just after storage and after the shelf life. The higher apple firmness was associated with their higher crunchiness expressed as a sensation of higher "noisiness" during tissue biting, what is highly appreciated by consumers. In the case of juiciness the differences noticeable when measured with instrumental (objective) method (Tab. 2) were not detected by sensory panel (Tab. 3). Finally the overall texture of fruits produced with both technologies was similarly scored in the range 5.6-5.9 in the 10points scale. Taking into consideration the challenge of supplying the market with apple fruit of the highest quality, it is worth mentioning, that in the current experiment, 'Topaz' apples produced in organic orchards lost their quality slightly slower than IP fruit what could aid their marketability.

Fruits from organic orchards (ECO) were perceived as less sweet and sourer than those grown in IP orchards (Tab. 3). While the perceived stronger sensation of sour taste in organic fruit was justified by its higher titratable acidity, the lack of correlations between soluble solids contents and fruit sweetness was connected with generally high sourness of evaluated samples that is characteristic for 'Topaz' variety. The effects of acidity on sweetness sensation were clearly visible after
7 days of shelf life, due to acidity decrease. In sensory tests, higher sweetness sensation was reported despite the invariable values of soluble solids contents. The perceived differences in sweet and sour taste intensity sensation for apples produced by both investigated methods did not influence their final taste harmonization or their overall eating quality (Tab. 3). Further, irrespectively of orchard management system, aroma of fully ripened apple, irrespectively whether checked on fruit cut into pieces (Tab. 3) or using whole fruit (Tab. 4) was perceived with similar intensity. Although for 'Topaz' we identified some differences between sweetness/sourness pattern for fruit produced with ECO and IP technology, finally results obtained stay in consensus with those reported by Adamczyk et al. (2006), Peck et al. (2006) or Nogy et al. (2012), who stated that the overall eating quality assessed by sensory methods is not dependent on orchard management system. However, many studies have unequivocally proved that vegetables and fruits from organic farms have a better taste and smell. Organic fruits are usually reported to contain more total sugars that these of conventional orchards, which probably influenced their better taste perception by consumers (Rembiałkowska, 2007).

\section{Appearance attractiveness}

On the contrary to internal quality, the differences in appearance of ECO and IP fruits were very distinct. The only trait perceived 
The comparison of sensory quality and processing...

Table 3. The influence of orchard management and shelf life on eating quality of 'Topaz' apple, data expressed in subjective units ( 0 -10 point's scale)

\begin{tabular}{|c|c|c|c|}
\hline \multirow[b]{2}{*}{ Shelf life } & \multicolumn{3}{|c|}{ Orchard management } \\
\hline & $\begin{array}{c}\text { ECO } \\
\text { organic }\end{array}$ & $\begin{array}{c}\text { IP } \\
\text { integrated }\end{array}$ & average \\
\hline \multicolumn{4}{|c|}{ Aroma of ripe apple } \\
\hline 1 & $3.0 \mathrm{a}^{*}$ & $3.4 \mathrm{a}$ & $3.2 \mathrm{~A}$ \\
\hline 7 & $3.7 \mathrm{a}$ & $3.7 \mathrm{a}$ & $3.7 \mathrm{~A}$ \\
\hline Average & $3.4 \mathrm{~A}$ & $3.6 \mathrm{~A}$ & \\
\hline \multicolumn{4}{|l|}{ Hardness } \\
\hline 1 & $5.5 \mathrm{c}$ & $4.7 \mathrm{ab}$ & $5.1 \mathrm{~A}$ \\
\hline 7 & $4.9 \mathrm{~b}$ & $4.4 \mathrm{a}$ & $4.6 \mathrm{~B}$ \\
\hline Average & $5.2 \mathrm{~B}$ & $4.5 \mathrm{~A}$ & \\
\hline \multicolumn{4}{|l|}{ Crunchiness } \\
\hline 1 & $5.4 \mathrm{a}$ & $4.8 \mathrm{a}$ & $5.1 \mathrm{~A}$ \\
\hline 7 & $4.8 \mathrm{a}$ & $4.1 \mathrm{~b}$ & $4.4 \mathrm{~B}$ \\
\hline Average & $5.1 \mathrm{~B}$ & $4.4 \mathrm{~A}$ & \\
\hline \multicolumn{4}{|l|}{ Juiciness } \\
\hline 1 & $5.0 \mathrm{ab}$ & $5.4 \mathrm{a}$ & $5.2 \mathrm{~A}$ \\
\hline 7 & $4.9 \mathrm{~b}$ & $4.8 \mathrm{~b}$ & $4.9 \mathrm{~B}$ \\
\hline Average & $5.0 \mathrm{~A}$ & $5.1 \mathrm{~A}$ & \\
\hline \multicolumn{4}{|l|}{ Overall texture } \\
\hline 1 & $6.1 \mathrm{a}$ & $6.2 \mathrm{a}$ & $6.1 \mathrm{~A}$ \\
\hline 7 & $5.8 \mathrm{a}$ & $5.2 \mathrm{~b}$ & $5.4 \mathrm{~B}$ \\
\hline Average & $5.9 \mathrm{~A}$ & $5.6 \mathrm{~A}$ & \\
\hline \multicolumn{4}{|l|}{ Sweet taste } \\
\hline 1 & $3.4 \mathrm{a}$ & $4.1 \mathrm{~b}$ & $3.7 \mathrm{~A}$ \\
\hline 7 & $4.1 \mathrm{~b}$ & $4.2 \mathrm{~b}$ & $4.2 \mathrm{~B}$ \\
\hline Average & $3.8 \mathrm{~A}$ & $4.2 \mathrm{~A}$ & \\
\hline \multicolumn{4}{|l|}{ Sour taste } \\
\hline 1 & $5.9 \mathrm{a}$ & $5.3 \mathrm{~b}$ & $5.6 \mathrm{~A}$ \\
\hline 7 & $5.3 \mathrm{~b}$ & $4.7 \mathrm{c}$ & $5.0 \mathrm{~B}$ \\
\hline Average & $5.6 \mathrm{~B}$ & $5.0 \mathrm{~A}$ & \\
\hline \multicolumn{4}{|l|}{ Flavour } \\
\hline 1 & $5.7 \mathrm{a}$ & $5.5 \mathrm{a}$ & $5.6 \mathrm{~A}$ \\
\hline 7 & $5.7 \mathrm{a}$ & $5.6 \mathrm{a}$ & $5.6 \mathrm{~A}$ \\
\hline Average & $5.7 \mathrm{~A}$ & $5.6 \mathrm{~A}$ & \\
\hline \multicolumn{4}{|l|}{ Overall quality } \\
\hline 1 & $5.4 \mathrm{a}$ & $5.7 \mathrm{a}$ & $5.6 \mathrm{~A}$ \\
\hline 7 & $5.3 \mathrm{a}$ & $5.2 \mathrm{~b}$ & $5.2 \mathrm{~B}$ \\
\hline Average & $5.6 \mathrm{~A}$ & $5.6 \mathrm{~A}$ & \\
\hline
\end{tabular}

*Means marked with the same letter do not significantly differ, Duncan MPR test, $\mathrm{p}<0.05$ 
D. Konopacka et al.

Table 4. The influence of orchard management on 'Topaz' apple appearance

Means and SD for 1 and 7 days of shelf life

\begin{tabular}{|c|c|c|c|}
\hline $\begin{array}{c}\text { Attribute } \\
\text { and } \\
0-10 \text { point's scale word anchors }\end{array}$ & $\begin{array}{c}\text { ECO } \\
\text { organic }\end{array}$ & $\begin{array}{c}\text { IP } \\
\text { integrated }\end{array}$ & p-level \\
\hline $\begin{array}{l}\text { Background colour } \\
0-\text { green; } 10-\text { yellow }\end{array}$ & $7.8 \pm 1.72$ & $7.8 \pm 1.59$ & 0.724 \\
\hline $\begin{array}{l}\text { Blush colour } \\
0 \text { - light red; } 10-\text { dark red }\end{array}$ & $7.9 \pm 1.43$ & $6.9 \pm 1.60$ & 0.000 \\
\hline $\begin{array}{l}\text { Percentage of blush } \\
0-0 \% ; 10-100 \%\end{array}$ & $7.6 \pm 1.33$ & $6.1 \pm 1.30$ & 0.000 \\
\hline $\begin{array}{l}\text { Aroma } \\
0-\text { no aroma; } 10 \text { - very intensive }\end{array}$ & $5.6 \pm 2.30$ & $6.1 \pm 2.23$ & 0.084 \\
\hline $\begin{array}{l}\text { Surface } \\
0 \text { - crude/matte; } 10 \text { - glossy/smooth }\end{array}$ & $4.6 \pm 1.52$ & $6.0 \pm 1.59$ & 0.000 \\
\hline $\begin{array}{l}\text { Russeting } \\
0-\text { no; } 10-100 \% \text { surface }\end{array}$ & $3.3 \pm 1.45$ & $2.0 \pm 1.10$ & 0.000 \\
\hline $\begin{array}{l}\text { Damages } \\
0-\text { lack; } 10-\text { meaningful }\end{array}$ & $1.8 \pm 1.91$ & $1.1 \pm 0.99$ & 0.000 \\
\hline $\begin{array}{l}\text { Shape regularity } \\
0 \text { - deformed; } 10 \text { - regular }\end{array}$ & $7.7 \pm 1.44$ & $8.2 \pm 1.45$ & 0.016 \\
\hline $\begin{array}{l}\text { Fruit size } \\
0-\text { small; } 10-\text { very big }\end{array}$ & $6.6 \pm 1.81$ & $5.9 \pm 1.37$ & 0.000 \\
\hline $\begin{array}{l}\text { Overall appearance } \\
0 \text { - unattractive; } 10 \text { - very attractive }\end{array}$ & $5.1 \pm 1.73$ & $6.5 \pm 1.36$ & 0.000 \\
\hline
\end{tabular}

similarly for fruits from both orchard systems was the yellowish background of skin colour, typical for 'Topaz' apples (Tab. 4). Fruits from organic orchards were characterized with larger and more intensive red blushes than those from IP system. Similar phenomenon of stronger and more extensive blush expression on organic apples than on fruit produced within the integrated system were also described by Adamczyk et al. (2006) and Weibel et al. (2000). The restricted crop protection treatments against pests and diseases in organic orchards resulted in a higher number of blemishes, scars and extensive rust compared to IP fruits negatively affecting organic apple attractiveness (Tab. 4). Further, the organic apples were characterized with rougher skin than those produced within IP system, what is typical for fruits grown in orchard without any chemical treatments. Moreover, the organic apples were perceived as less regular in shape and despite of generally bigger size also were more diversified than IP fruit. This is reflected by a higher standard deviation (Tab. 4). Finally, the overall appearance attractiveness of organic fruit was judged significantly lower than IP fruits what usually indicates lower product marketability. Nevertheless consumers oriented toward bioproducts may not pay special attention to some appearance defects of fruit considering other their advantages (Weibel and Grab, 2000). 
The comparison of sensory quality and processing...

\section{Processing potential}

Generally, the obtained results indicate that both ECO and IP apples did not differ much in chemical composition, thus revealing similar processing usefulness (Tab. 2). However, the observed higher titratable acidity of organic than IP fruit, also detectable within sensory evaluation and also holding on during shelf life (Tab. 3), gives the real possibility of exploiting this characteristic as processing advantage. According to Markowski et al., (2007) 'Topaz' cultivar can be used as raw material suitable for production of different apple products such as clear and cloudy apple juice as well as apple puree, nevertheless products processed exclusively of 'Topaz' may not be fully accepted by consumers due to their high acidity. However, just this high natural acidity of 'Topaz' apple, strengthened by organic technology, could favour potential application of ECO 'Topaz' fruit as the additive regulating acidity and shape the desirable sensory traits of other less acidic processed organic products.

\section{CONCLUSIONS}

1. The results of internal sensory assessment did not explicitly demonstrate the effect of the compared orchard management systems. Although the fruits from organic orchards were perceived as slightly firmer, less sweet and sourer, than IP fruit, they did not differ in overall eating quality. There was no significant effect of the growing system on the quality traits connected with aroma assessment.

2. Fruits from organic orchards had significantly stronger blush colour covering the higher percentage of apple skin; however they were more differentiated in shape and size. More frequently than in the case of IP apples there were observed marks, scars and rust, which negatively affected their attractiveness.

3. Analysis of the chemical composition of fruits indicates that apple from organic orchards are characterized by higher titratable acidity and soluble solids content, which could favour their potential application as the additive regulating acidity and shape the desirable sensory traits of processed organic products.

Acknowledgment: The work has been supported by a grant from the EU Regional Development Fund through the Polish Innovation Economy Operational Program, contract N. UDAPOIG.01.03.01-10-109/08-00

\section{REFERENCES}

Adamczyk M., Rembiałkowska E., Wasiak-Zys G. 2006. The comparison of sensory quality of apples from organic and conventional production and after storage. ŻYWNOŚĆ NAUKA TECHNOLOGIA JAKOŚC 2 (47) Supl.: 11-19 (abstract in English).

Błaszczyk J. 2006. The influence of harvest date on the storability 'Topaz' apples. ZESZ. NAUK. INST. SADOW. KWIAC. Tom 14: 87-93 (abstract in English). 
D. Konopacka et al.

Bryk H. 2006. Perspektywy ochrony sadów przed chorobami w systemie ekologicznym. POST. OCHR. ROŚLIN 46 (1): 424-432.

Bryk H., Kruczyńska D. 2011. Possibilities in growing and protection of apple trees against diseases in organic orchards. Journal of Research and Applications in AGRIC. ENG. 56(3): 40-44.

Cmelik Z., Zadravec P., Tojnko S., Schlauer B., Vogrion A., Unuk T. 2007. Sensory evaluation of fruit of some organically grown scab resistant. ACTA HORT. 737: (53-58).

Czynczyk A., Mika A., Bielicki P., Krawiec A. 2008. Suitability evaluation of several apple cultivars for organic fruit production. J. FRUIT ORNAM. PLANT RES. 16: 7-15.

Dangour A.D., Dodhia S.K., Hayter A., Allen E., Lock K., Uauy R. 2009. Nutritional quality of organic foods: a systematic review. AM. J. CLIN. NUTR. 90(3): 680-685.

Konopacka D., Jesionkowska K., Rutkowski K., Płocharski W., Tomala K. 2006. A comparison of the quality of well known and scab resistant apples in expert and consumer evaluation. VEG. CROPS RES. BULL. 65: 185-194.

Konopacka D., Płocharski W.J. 2001. The relationship between firmness and juiciness of 'Elstar', 'Gloster' and 'Jonagold' apples. J. FRUIT ORNAM. PLANT RES. 9(1-4): 9-17.

Kruczyńska D.E, Rutkowski K.P. 2006. Quality and storage of Czech scab resistant apple cultivars. PHYTOPATHOL. POL. 39: 53-61.

Markowski J., Kołodziejczyk K., Król B., Płocharski W., Rutkowski W. 2007. Phenolics in apples and processed apple products. POL. J. FOOD NUTR. SCI. 57: 383-388.

Nagy P.T., Nyéki J., Szabó Z. 2012. Are organic apples really healthier? ACTA HORT. (ISHS) 933: 607-611.
Peck G.M, Andrews P.K., Reganold J.P., Fellman J.K. 2006. Apple orchard productivity and fruit quality under organic, conventional, and integrated management. HORTSCI. 41: 99-107.

Pitera E. Growth and initial bearing of scab resistant apple cultivars under conditions of limited fungicide use. 2006. PHYTOPATHOL. POL. 39: 49-52.

Rembiałkowska E. 2007. Quality of plant products from organic agriculture. J. SCI. FOOD AGRIC., 87: 2757-2762.

Vavra R., Bocek S. 2010. Apple scab (Venturia inaequalis (Cooke) Wint.) attacks on cultivars and genotypes carrying different resistant genes in plantings with breaking through $V f$ Rvi6 gene. 14th Inter. Conf. Organic Fruit-Growing, Hohenheim, Germany, 22-24.02.2010: 10-15.

WE. 2007. Rozporządzenie Rady (WE) nr 834/2007 z dnia 28 czerwca 2007 r. w sprawie produkcji ekologicznej i znakowania produktów ekologicznych. Dziennik Urzędowy Unii Europejskiej L 189/1.

Weibel F.P., Bickel R., Leuthold S., Alfoldi T. 2000. Are organically grown apple testier and healthier? A comparative field study using convectional and alternative methods to measure fruit quality. ACTA HORT. (ISHS) 517: 417-426.

Weibel F.P., Grab F. 2000. Sustainable production needs sustainable marketing: Evaluation of a new marketing concept to introduce organically grown scab (Venturia inaequalis) resistant apple varieties at the Swiss supermarket retailer Coop. In: Thomas Alföldi et al. (eds), Proceedings of the 13th Int. IFOAM Scientific Conference. FiBL, Basel., pp. 255-258.

Weibel F.P., Kruczyńska D., Konopacka D., 2012. Consumer preference of apple cultivars suited for organic 
The comparison of sensory quality and processing...

production and which factors influence the buying decision (Conference Paper) ACTA HORT. 933: 645-652.

Zmarlicki K. 2009. Market of organic fruit in consumer opinions. In: Polish Horticulture in context of globaliza- tion and increasing interest in organic products. Scientific Conference on Horticulture Economics, ISK Skierniewice, 30 September 2009, pp. 47-50 (in Polish).

\title{
PORÓWNANIE JAKOŚCI SENSORYCZNEJ ORAZ POTENCJAŁU PRZETWÓRCZEGO JABŁEK 'TOPAZ' POCHODZĄCYCH Z SADÓW EKOLOGICZNYCH ORAZ PROWADZONYCH METODAMI PRODUKCJI INTEGROWANEJ
}

\author{
Dorota Konopacka, Urszula Grzyb, Aneta Matulska, \\ Anna Wawrzyńczak, Dorota Kruczyńska \\ i Krzysztof P. Rutkowski \\ S T R E S Z C Z E N I E
}

Celem badań było porównanie cech jakościowych oraz jakości sensorycznej jabłek odmiany Topaz pochodzących z certyfikowanych sadów ekologicznych (ECO) z owocami wyprodukowanymi metodami integrowanymi (IP) oraz ich przydatności technologicznej dla przetwórstwa. Owoce zbierano w pięciu sadach certyfikowanych ECO oraz IP $w$ stanie dojrzałości zbiorczej i przechowywano przez dwa miesiące $\mathrm{w}$ chłodni $\mathrm{w}$ atmosferze normalnej $\mathrm{i} w$ temperaturze $1^{\circ} \mathrm{C}$. Jakość owoców oceniano po dodatkowych 1 i 7 dniach przechowywania w temperaturze $18{ }^{\circ} \mathrm{C}$. Owoce z sadów ekologicznych charakteryzowały się większym zróżnicowaniem pod względem kształtu i wielkości. Częściej występowały na nich skazy i blizny oraz ordzawienia wpływające na obniżenie atrakcyjności ich wyglądu zewnętrznego w stosunku do owoców IP. Ocena sensoryczna jakości wewnętrznej owoców nie wykazała jednoznacznie wpływu porównywanych technologii uprawy na walory smakowe ocenianych jabłek. Chociaż owoce z sadów ekologicznych były postrzegane jako mniej słodkie i bardziej kwaśne, nie wpłynęło to na ogólną ocenę jakości konsumpcyjnej. Nie zaobserwowano też wpływu technologii na cechy związane z aromatem i ogólną oceną tekstury. Analizy podstawowego składu chemicznego owoców wskazuja, że jabłka z sadów ekologicznych charakteryzują się średnio wyższą kwasowością oraz wyższą zawartością ekstraktu, co może skłaniać do ich potencjalnego wykorzystywania jako dodatku regulującego kwasowość i sprzyjającego kształtowaniu pożądanych cech sensorycznych w przetworach ekologicznych.

Słowa kluczowe: produkcja ekologiczna, jakość owoców, atrakcyjność sensoryczna, skład chemiczny, przydatność dla przetwórstwa 